\title{
The Linkage relationship between the development of secondary industry and environmental pollution: a case in Fujian
}

\author{
GAO Ling ${ }^{1 *}$, JIANG Wenting ${ }^{2}$ \\ ${ }^{1}$ College of Economics and Management, Fuzhou University, Fuzhou, 350106, China \\ ${ }^{2}$ College of Economics and Management, Fuzhou University, Fuzhou, 350106, China \\ * Corresponding Author's e-mail: gr003043@163.com
}

\begin{abstract}
Fujian is very wealthy in natural resources, which provides a good environment for social development and people's life. However, with the development of economy, environmental pollution has become an importation problem in Fujian. In order to discuss the linkage relationship between economic development and environmental pollution, this paper selects the data of the secondary industry, industrial waste gas emissions, industrial waste water emissions and industrial solid waste production from 1995 to 2017 in Fujian, establishes the VAR model, explore the relationship between the development of secondary industry and environmental pollution. The results show that the association between the development of the secondary industry and environmental pollution is monotonously increasing. The industrial waste gas has become the main pollutant restricting the development of the secondary industry. Industrial solid waste has made the largest contribution to the development of the secondary industry, indicating a positive dynamic correlation.
\end{abstract}

\section{Introduction}

In recent years, the economy of Fujian has developed rapidly. In 2017, the GDP of Fujian reached 3218.209 billion yuan, the GDP of the secondary industry reached 1535.429 billion yuan. The proportion of the secondary industry ranked first. With the continuous growth of Fujian economy and the improvement of industrialization level, environmental pollution in Fujian has gradually become the focus of attention. During the 13th Five Year Plan period, Fujian continued to promote the development of green industry, but there are still many industries with high energy consumption, and the resulting industrial "three wastes" have caused great environmental pollution. The environmental problems such as water, air, solid waste and other environmental problems are described in detail in "Fujian Environmental Status Bulletin in 2017". Although in recent years, in response to the call of the central government and focusing on the pollution problems, some achievements have been made, but the overall situation of environmental protection is still not optimistic. Therefore, to study the relationship between the development of the secondary industry and environmental pollution in Fujian, and make targeted recommendations, it has important practical significance.

\section{Literature review}

With the development of society, environmental problems have become the bottleneck of economic development, economic development and environmental pollution have become an associated relationship. Grossman and
Krueger found that there is an inverted $\mathrm{U}$ curve between environmental pollution and per capita income [1]. Michael E. Porter. et al. think that environmental protection and industrial development are equally important, only when they complement each other can long-term economic and social benefits be achieved [2]. Based on the empirical test of provincial panel data, Cheng Bo analyzed the relationship among economic growth, institutional environment and air pollution [3]. Tian Zhihua. et al. built VEC model to study the dynamic relationship between environmental pollution and per capita GDP in Guangdong [4]. Based on decoupling theory, Wu Dandan construct the decoupling index model of IPAT equation to reveal the relationship between economic development and environmental pollution in coastal cities of China [5]. Qi Yuan. et al. use panel data and time series analysis to study the impact of industrial $\mathrm{SO} 2$ on industrial structure change in Beijing Tianjin Hebei region [6]. Li Shu build a GMM model with the provincial panel data, demonstrate the impact of urbanization and industrial structure optimization and upgrading on environmental pollution [7]. Li Peng confirm that the "inverted U" curve exists between the industrial structure and the total amount of environmental pollution emissions [8].

To sum up, the research on the relationship between the development of secondary industry and environmental pollution mainly includes time series, EKC curve verification, spatial econometrics and other methods. Most of these studies combine economic development with environmental pollution, while few studies combine the secondary industry as an independent factor with environmental pollution. Most of these literature adopts the comprehensive index of three industries as the research object, while only a few of the literatures adopts a specific 
industry. Although the comprehensive index is concise, there are inevitably errors in the weight setting and index calculation. Therefore, this paper selects the proportion of the secondary industry as an independent factor and environmental pollution, establishes a Vector Autoregressive model (VAR model) to analyzes the linkage relationship between them.

\section{Indicator selection and variable de- scription}

This paper selects the time series data of the proportion of secondary industry and environmental pollution in Fujian from 1995 to 2017.

The proportion of the secondary industry refers to the proportion of the secondary industry in GDP of Fujian; the environmental pollution indicators are industrial waste gas emission, industrial waste water emissions and industrial solid waste production. The data in this paper are from China Statistical Yearbook (1996-2018) and Fujian Statistical Yearbook (1996-2018) (Table1).

Table1. Raw data sheet

\begin{tabular}{|c|c|c|c|c|c|c|c|c|c|}
\hline \multirow[t]{2}{*}{ year } & $\begin{array}{c}\text { Proportion } \\
\text { of the sec- } \\
\text { ondary in- } \\
\text { dustry }\end{array}$ & $\begin{array}{l}\text { Industrial } \\
\text { waste gas } \\
\text { emissions }\end{array}$ & $\begin{array}{c}\text { Industrial } \\
\text { waste } \\
\text { water } \\
\text { emissions }\end{array}$ & $\begin{array}{l}\text { Industrial } \\
\text { solid } \\
\text { waste pro- } \\
\text { duction }\end{array}$ & \multirow[t]{2}{*}{ year } & $\begin{array}{l}\text { Proportion } \\
\text { of the } \\
\text { secondary } \\
\text { industry }\end{array}$ & $\begin{array}{l}\text { Industrial } \\
\text { waste gas } \\
\text { emissions }\end{array}$ & $\begin{array}{c}\text { Industrial } \\
\text { waste wa- } \\
\text { ter emis- } \\
\text { sions }\end{array}$ & $\begin{array}{c}\text { Industrial } \\
\text { solid } \\
\text { waste } \\
\text { production }\end{array}$ \\
\hline & $(\%)$ & $\begin{array}{l}\text { billion cu- } \\
\text { bic meters }\end{array}$ & $\begin{array}{l}\text { ten thou- } \\
\text { sand ton }\end{array}$ & $\begin{array}{l}\text { ten thou- } \\
\text { sand ton }\end{array}$ & & $(\%)$ & $\begin{array}{l}\text { billion cu- } \\
\text { bic meters }\end{array}$ & $\begin{array}{l}\text { ten thou- } \\
\text { sand ton }\end{array}$ & $\begin{array}{c}\text { ten thousand } \\
\text { ton }\end{array}$ \\
\hline 1996 & 41.8 & 1827 & {$[8411$} & 747 & 2007 & 48.4 & $91\lceil 3$ & $13 C 408$ & 4815 \\
\hline 1997 & 43.1 & 1946 & {$[, 5194$} & $104 c$ & 2008 & 49.1 & 9150 & 139997 & 5371 \\
\hline 1998 & 43.4 & 2007 & 2482 & 1080 & 2009 & 49.1 & 10497 & 142747 & 349 \\
\hline 1999 & 42.5 & 2321 & {$[3,20$} & 1590 & 2010 & 51.0 & $13\lceil 07$ & 124198 & 7487 \\
\hline 2000 & 43.7 & 2828 & 57617 & 2191 & 2011 & 51.6 & 14973 & 316178 & 4415 \\
\hline 2001 & 44.8 & 3305 & 9724 & $\lceil 133$ & 2012 & 51.7 & 14739 & $25 c_{2} c_{3}$ & 7720 \\
\hline 2002 & $4 c .1$ & $3 \sqrt{65} 5$ & $78\lceil, 11$ & 4131 & 2013 & 51.8 & 16183 & $2\lceil, 9098$ & $8[3 \sqrt{5}$ \\
\hline 2003 & $47 . ?$ & 4189 & 98388 & 2981 & 2014 & 2.0 & 18383 & $260\lceil 79$ & 4835 \\
\hline 2004 & 48.0 & 5020 & 115,228 & 3301 & 2015 & 50.3 & 17204 & $25 c 88$ & 4956 \\
\hline $200 \Gamma_{5}$ & 48. 5 & 265 & 130939 & 3773 & 2016 & 48. 5 & $177 \% 1$ & 237010 & 4449 \\
\hline 2006 & 48.7 & 6884 & $127\lceil 83$ & 4238 & 2017 & 47.7 & 17139 & 238279 & $54 r_{2}$ \\
\hline
\end{tabular}

Data sources: China Statistical Yearbook and Fujian statistical yearbook from 1996 to 2018.

The specific definition of variables is shown in Table 2. The data analysis software is Eviews9.0.

Table 2. Variable description

\begin{tabular}{|c|c|c|c|c|c|}
\hline $\begin{array}{c}\text { Variable } \\
\text { abbreviation }\end{array}$ & Definition & $\begin{array}{c}\text { Variable ab- } \\
\text { breviation }\end{array}$ & Definition & $\begin{array}{c}\text { Variable ab- } \\
\text { breviation }\end{array}$ & Definition \\
\hline Gas & $\begin{array}{l}\text { Industrial waste gas } \\
\text { emission }\end{array}$ & LnGas & $\begin{array}{c}\text { Industrial waste } \\
\text { gas emissions after } \\
\text { logarithm }\end{array}$ & DLnGas & $\begin{array}{l}\text { Industrial waste gas emis- } \\
\text { sions after difference }\end{array}$ \\
\hline Water & $\begin{array}{c}\text { Industrial waste water } \\
\text { emissions }\end{array}$ & LnWater & $\begin{array}{l}\text { Industrial waste } \\
\text { water emissions } \\
\text { after logarithm }\end{array}$ & DLnWater & $\begin{array}{l}\text { Industrial waste water } \\
\text { emissions after differ- } \\
\text { ence }\end{array}$ \\
\hline Solid & $\begin{array}{l}\text { Industrial solid waste } \\
\text { production }\end{array}$ & LnSolid & $\begin{array}{l}\text { Industrial solid } \\
\text { waste production } \\
\text { after logarithm } \\
\end{array}$ & DLnSolid & $\begin{array}{l}\text { Industrial solid waste } \\
\text { production after differ- } \\
\text { ence }\end{array}$ \\
\hline Secondary & $\begin{array}{l}\text { Proportion of second- } \\
\text { ary industry }\end{array}$ & LnSecondary & $\begin{array}{l}\text { Proportion of sec- } \\
\text { ondary industry } \\
\text { after logarithm }\end{array}$ & $\begin{array}{l}\text { DLnSecond- } \\
\text { ary }\end{array}$ & $\begin{array}{l}\text { Proportion of secondary } \\
\text { industry after difference }\end{array}$ \\
\hline
\end{tabular}

This paper analyzes the relationship between the development of secondary industry and environmental pollution with VAR model in Fujian. The mathematical expression of VAR model is as follows:

$Y_{t}=a_{1} Y_{t-1}+\ldots+a_{p} Y_{t-p}+\beta X_{t}+\delta_{t}$

\section{(1)}

Variable explanation: $Y_{t}$ is a K-dimensional endogenous variable; $X_{t}$ is an exogenous variable; $a_{1} \cdots a_{p}$ and $\beta$ are the parameter matrix to be estimated; the endogenous variable has p-order lag; $\delta_{t}$ is a random disturbance vector; VAR (P) express a VAR model with $\mathrm{p}$ order lag of endogenous variables.

\section{Establishment of VAR model}

\subsection{ADF stationarity test}

In order to avoid the problem of "pseudo regression", it is necessary to test the stationarity of the data. In this paper, ADF test (Augmented Dickey-Fuller test) is used to test 
the stationarity of the data related to the secondary industry and environmental pollution in Fujian (Table 3). The results show that there are trend terms in LnGas, LnWater, LnSolid and LnSecondary. Therefore, the principle of testing trend items first should be followed. After testing, LnGas, LnWater, LnSolid and LnSecondary have a unit root, so the original sequence is not stable; after the firstorder difference of the original sequence, DLnGas, DLnWater, DLnSolid and DLnSecondary do not have unit root, which proves that the sequence after the first-order difference is stable.

Table 3. ADF stability test

\begin{tabular}{|c|c|c|c|c|c|c|}
\hline Sequence & $\begin{array}{c}\text { Inspection } \\
\text { form }\end{array}$ & ADF value & $\begin{array}{c}\mathbf{5 \%} \text { signifi- } \\
\text { cant level }\end{array}$ & $\begin{array}{c}\text { 10\% signifi- } \\
\text { cant level }\end{array}$ & Pro.value & $\begin{array}{c}\text { Examina- } \\
\text { tion and } \\
\text { judgment }\end{array}$ \\
\hline LnGas & $(\mathrm{C}, \mathrm{T}, \mathrm{O})$ & 0.216771 & -3.658446 & -3.268973 & 0.9962 & $\begin{array}{c}\text { Not signifi- } \\
\text { cant }\end{array}$ \\
\hline DLnGas & $(\mathrm{N}, \mathrm{T}, \mathrm{O})$ & -3.89627 & -3.012363 & -2.646119 & 0.0079 & $\begin{array}{c}\text { Remarka- } \\
\text { ble }\end{array}$ \\
\hline LnWater & $(\mathrm{C}, \mathrm{T}, \mathrm{O})$ & -3.144802 & -3.632896 & -3.254671 & 0.1210 & $\begin{array}{c}\text { Not signifi- } \\
\text { cant }\end{array}$ \\
\hline DLnWater & $(\mathrm{N}, \mathrm{T}, \mathrm{O})$ & -5.898554 & -3.012363 & -2.646119 & 0.0001 & $\begin{array}{c}\text { Remarka- } \\
\text { ble }\end{array}$ \\
\hline LnSolid & $(\mathrm{C}, \mathrm{T}, \mathrm{O})$ & -1.830518 & -3.632896 & -3.254671 & 0.6551 & $\begin{array}{c}\text { Not signifi- } \\
\text { cant }\end{array}$ \\
\hline DLnSolid & $(\mathrm{N}, \mathrm{T}, \mathrm{O})$ & -4.807047 & -3.012363 & -2.646119 & 0.0011 & $\begin{array}{c}\text { Remarka- } \\
\text { ble }\end{array}$ \\
\hline LnSecondary & $(\mathrm{C}, \mathrm{T}, \mathrm{O})$ & 0.544790 & -3.632896 & -3.254671 & 0.9987 & $\begin{array}{c}\text { Not signifi- } \\
\text { cant }\end{array}$ \\
\hline DLnSecondary & $(\mathrm{N}, \mathrm{T}, \mathrm{O})$ & -3.039204 & -3.012363 & -2.646119 & 0.0474 & $\begin{array}{c}\text { Remarka- } \\
\text { ble }\end{array}$ \\
\hline
\end{tabular}

Note: the test form $(\mathrm{C}, \mathrm{t}, \mathrm{K})$ indicates intercept, trend and lag respectively;

$\mathrm{N}$ and 0 indicate that there is no corresponding item.

\subsection{Determination of lag order}

In general, the optimal lag time of VAR model is determined according to the criterion of minimum information of AIC and SC. It can be seen in table 4 that among the 6 evaluation indexes, including AIC, SC, FPE and HQ, lag phase 1 is selected as the optimal lag period. Therefore, this paper determines the model of VAR (1).

Table 4. Optimal lag time of VAR model

\begin{tabular}{|c|c|c|c|c|c|c|}
\hline Lag & LogL & LR & FPE & AIC & SC & HQ \\
\hline 1 & 124.0135 & NA & $4.08 \mathrm{e}-10^{*}$ & $-10.28700^{*}$ & $-9.491175^{*}$ & $-10.11429^{*}$ \\
\hline 2 & 131.3097 & 9.033372 & $1.08 \mathrm{e}-09$ & -9.458066 & -7.866413 & -9.112637 \\
\hline
\end{tabular}

Note: * indicates that the lag order of the marked value in the row is the best lag order recommended by the inspection standard of the column in which the value is located.

In this paper, Johansen cointegration test method is used

\subsection{Johansen cointegration test} to test the cointegration relationship between the proportion of secondary industry and environmental pollution (Table 5).

Table 5. Johansen cointegration test

\begin{tabular}{|l|l|l|l|l|l|l|}
\hline & $\begin{array}{l}\text { Original hy- } \\
\text { pothesis }\end{array}$ & $\begin{array}{l}\text { Character- } \\
\text { istic root }\end{array}$ & $\begin{array}{l}\text { Statistical } \\
\text { value }\end{array}$ & $\begin{array}{l}\mathbf{5 \%} \text { critical } \\
\text { value }\end{array}$ & $\begin{array}{l}\text { Probability p } \\
\text { value }\end{array}$ & Conclusion \\
\hline Trace statistics & None & 0.765464 & 53.85490 & 47.85613 & 0.0123 & Refuse \\
\hline & At most 1 & 0.489784 & 21.95166 & 29.79707 & 0.3012 & Accept \\
\hline Maximum eigenvalue & None * & 0.765464 & 31.90323 & 27.58434 & 0.0130 & Refuse \\
\hline & At most 1 & 0.489784 & 14.80425 & 21.13162 & 0.3028 & Accept \\
\hline
\end{tabular}

According to the test and judgment of trace statistics:

The original hypothesis is None, the trace statistics value is $53.85490>$ the critical value $47.85613, \mathrm{P}$ value is $0.0123<0.05$, we reject the original hypothesis and think that there is at least one cointegration relationship.

- $\quad$ The original hypothesis is At most 1 , the trace statistic value is $21.95166<$ the critical value $29.79707, \mathrm{P}$ value $0.3012>0.05$, we accept the original hypothesis and think that there is at most one cointegration relationship.
The test results of the maximum eigenvalue are consistent with the results of trace statistics. Therefore, Johansen cointegration test shows that there is only one cointegration relationship between the second industry and environmental pollution.

\section{Empirical analysis}

\subsection{Stability of VAR model}


According to the above test, the VAR (1) model is established and the VAR model equation is obtained:

Ln Sec ondary $=0.783764721337 *$ Ln Sec ondary (-

1) $+0.009535358226 *$ LnSolid (-1)-0.00542893098245*

LnGas (-1)+0.000595693001726* LnWater (-

1) +0.256401638726

(2)

\begin{tabular}{ll}
\hline \hline \multicolumn{1}{c}{ Root } & Modulus \\
\hline \hline 0.932971 & 0.932971 \\
$0.690290-0.221719 \mathrm{i}$ & 0.725024 \\
$0.690290+0.221719 \mathrm{i}$ & 0.725024 \\
0.073665 & 0.073665 \\
\hline \hline
\end{tabular}

No root lies outside the unit circle.

VAR satisfies the stability condition.

Figure 1. VAR root graph

\subsection{Impulse response function}

This paper analyzes the relationship between LnSecondary and LnGas, LnWater, LnSolid through impulse response function. The number of lag periods is selected as 20 , which is convenient for more detailed observation of the trend (Figure 3).

\subsubsection{The pulse response between the growth of}

the secondary industry and the industrial waste gas emissions

When a standard deviation is given to the proportion of the secondary industry, the response of industrial waste gas to the proportion of the secondary industry shows an upward trend in the first four periods. In the fifth period, it declined until it is close to zero. The total cumulative response value is 0.003562 , which indicates that the development of the secondary industry will increase the emission of industrial waste gas; When a standard deviation impact is given to the industrial waste gas emission, the response value of the proportion of the secondary industry to the industrial waste gas in the current period is 0 , and the cumulative response cumulative value is negative, which indicates that the more serious the pollution problem of industrial waste gas, the more impact on the development of the secondary industry. This is because air pollution not only seriously affects people's normal life, but also starts to hinder the normal development of social economy.

\subsubsection{The pulse response between the growth of the} secondary industry and the emission of industrial waste water
The R2 values are $0.957431,0.823774,0.992022$ and 0.953301 , indicating that the fitting degree of the model is high. If the estimated VAR model is stationary, then the reciprocal modulus of all the roots of the model is less than 1 , and all of them fall in the unit circle. Otherwise, it means that the estimated VAR model is unstable. It can be seen from Figure 1 and Figure 2 that the estimated VAR model is stable.

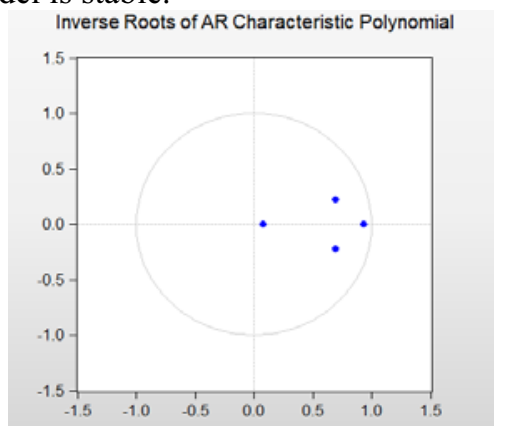

Figure 2. Modular graph of reciprocal

When the proportion of the secondary industry is impacted by a standard deviation, the current response value of the industrial waste water to the secondary industry is 0 , the total cumulative response value is 0.00338 , which indicates that the development of the secondary industry increases the industrial waste water emissions; when the industrial waste water is impacted by a standard deviation, the current response value of the proportion of the secondary industry to the industrial waste water is 0 . The product response values are all positive, indicating that with the increase of industrial waste water emission, the secondary industry value will also increase, and the reaction mechanism of industrial waste water on the secondary industry has not been reflected.

5.2.3 The pulse response between the growth of secondary industry and the production of industrial solid waste

When a standard deviation is given to the secondary industry, the impact response of industrial solid waste to the secondary industry is in a downward trend in the first five periods, reaches the lowest level is 0.000515 . The total cumulative response value is 0.03274 . On the whole, the industrial solid waste production in the second industry have a positive impact, and the inverted $\mathrm{N}$-type curve, it also shows that the development of the secondary industry is the important cause leading to the industrial solid waste; When the industrial solid waste production quantity is impacted by a standard deviation, the response value in the current period is 0 . The cumulative response value is positive, indicating that there is an interactive relationship between the solid waste production quantity and the secondary industry, and the reaction mechanism of environmental pollution on the industrial structure has not been reflected. 

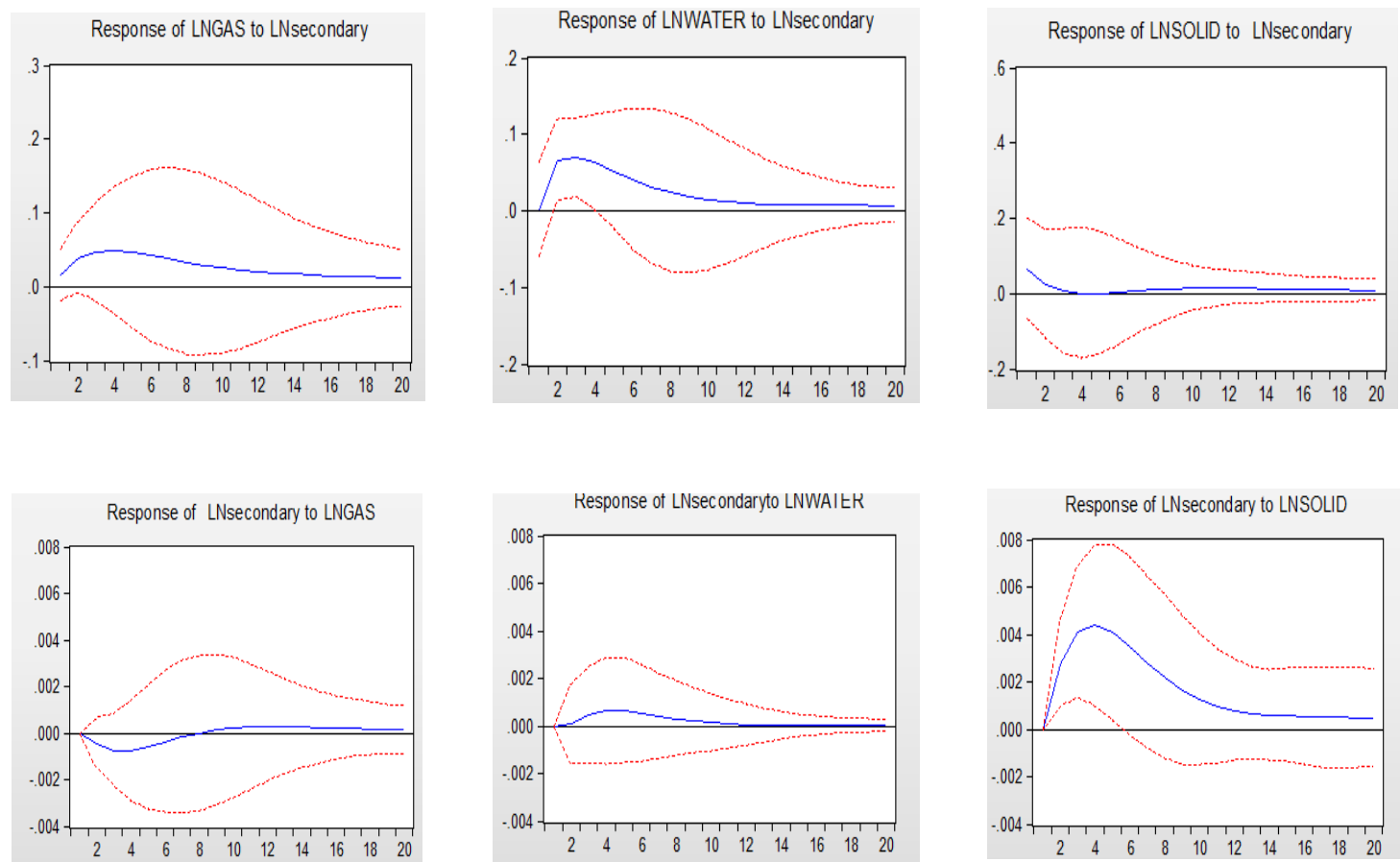

Figure 3. Impulse response function

From the above impulse response function analysis, it can be seen that the development of the secondary industry is an important cause of environmental pollution. Among all kinds of environmental pollution indicators, the cumulative value of industrial solid waste production is the largest.

\subsection{Variance decomposition}

The purpose of variance decomposition based on VAR model is to evaluate the interaction between the secondary industry and environmental pollution, analyze the relative contribution degree of a disturbance factor to the variables in the system according to the contribution rate. According to the evaluation standard of average contribution degree, it can be seen from table 6 that among the contribution rates of each environmental pollutant to the secondary industry, the average degree of industrial solid waste production is 46.616688 , the impact degree is relatively large. The industrial waste gas emission is 0.7471784 , the industrial waste water emission is 1.156367 , both of which have a relatively small influence degree. This is consistent with the above impulse response function analysis (Table 6).

Table 6. Contribution of three types of environmental pollutants to the secondary industry

\begin{tabular}{|c|c|c|c|}
\hline Variance Period & LnSolid & LnGas & LnWater \\
\hline 1 & 0.000000 & 0.000000 & 0.000000 \\
\hline 2 & 19.46032 & 0.483106 & 0.016346 \\
\hline 3 & 37.16723 & 1.127117 & 0.328014 \\
\hline 4 & 48.15212 & 1.448279 & 0.661556 \\
\hline 5 & 54.64120 & 1.524929 & 0.897030 \\
\hline 6 & 58.45721 & 1.484856 & 1.036758 \\
\hline 7 & 60.67680 & 1.415751 & 1.107946 \\
\hline 8 & 61.94068 & 1.364941 & 1.137191 \\
\hline 9 & 62.64334 & 1.349095 & 1.144487 \\
\hline 10 & 63.02798 & 1.365596 & 1.142456 \\
\hline Average & 46.616688 & 1.156367 & 0.7471784 \\
\hline
\end{tabular}

\section{Conclusion}

In this paper, the proportion of the secondary industry and three representative indicators of environmental pollution--industrial waste gas emissions, industrial wastewater emissions, industrial solid waste production are selected in Fujian from 1995 to 2017, establish a VAR model to study the dynamic relationship between each other. The analysis shows that: (1) There is an interaction 
between the development of the secondary industry and environmental pollution; (2) The contribution of the development of the secondary industry to environmental pollution is more obvious. With the development of the secondary industry, the emission of the "three wastes" of the industry also increased significantly, showing a monotonous rising relationship, that is, the environment gradually deteriorated with the economic development; (3) The industrial waste gas emission has a great impact on the development of the secondary industry, which indicates that the problem of atmospheric environmental pollution has been relatively serious and has become an important factor to inhibit the economic development of $\mathrm{Fu}-$ jian; (4) There is a positive correlation between the discharge of industrial waste water and the production of industrial waste with economic development, among which the production of industrial waste has the highest contribution to economic growth.

In view of this, to achieve green development, Fujian must start from the following aspects: (1) We must optimize the industrial structure, vigorously develop new and clean energy, eliminate the seriously polluted traditional industries, or transform the traditional industries with high level and new technology, advocate a low-carbon economy and circular economy;(2) Strengthen the inspection of industrial "three wastes", closely observe the air quality, set time limit requirements for enterprises to control pollution, and increase the sense of responsibility and supervision of local governments; (3) Set up incentive mechanism to encourage enterprises to research and develop environmental protection technologies and materials, implement environmental pollution reporting incentive system, so as to achieve coordinated development of economic benefits and environmental quality.

\section{References}

1. Grossman G. M, Krueger A.B. (1991) Environmental Impacts of a North American Free Trade Agreement, Cambridge: NBER Working Paper, No: 3914.

2. Michael E.Porter, Claas van der Linde.(1995) Toward a New Conception of the EnvironmentCompetitiveness Relationship, The Journal of Economic Perspectives(04):pp.97-118.

3. Cheng Bo, he Lei, Ruan Chenghua (2018) Economic growth, institutional environment and air pollution: An Empirical Test Based on Provincial Panel Data, Journal of Chongqing University of technology and technology (01):pp.3032.

4. Tian Zhihua, Wang Zhong. (2013) Dynamic relationship between environmental pollution and economic growth in Guangdong Province: An Empirical Study Based on vector error correction model, Journal of Guangdong University of Commerce(06):pp.4-10.

5. Wu Dandan, Ma Renfeng, Wang Tengfei, Zhou Guoqiang (2016) Decoupling of economic growth and environmental pollution in coastal cities of China, Research and development of world science and technology (02):pp.415-418.

6. Qi Yuan, Zhang Yong'an. (2015) Relationship between industrial structure evolution and industrial sulfur dioxide emission -- a case study of Beijing Tianjin Hebei, Urban issues (06):pp.54-62.

7. Li Shu. (2011) Urbanization, industrial structure adjustment and environmental pollution, Research on financial issues (06):pp.38-43.

8. Li Peng. (2016) The test of inverted "U" curve relationship between industrial structure and environmental pollution -- Based on the adjustment range of industrial structure and economy, Economic problem (10):pp.21-26. 